\title{
Energy Efficiency Optimization Of Three Phase Induction Motor Drives For Industrial Applications
}

\author{
Omorogiuwa Eseosa, Ayor Christian
}

\begin{abstract}
Worldwide applications of electric motors for industrial purposes show that, about 60 percent of electrical power generated is consumed by electric motors. This has led to increase in production cost and environmental pollution as more energy demand implies more operating cost. This work aims to appreciably reduce this huge amount of energy demand by electric motors via the use of energy efficient optimization options. This work is concerned with three phase induction motor drive control technique. Although there are diverse control strategies, however search control method using V/f controller having torque versus frequency voltage matrix injected into the drive input is adopted. This method relies on the fact that, at specified values of speed and torque, (called operating point), there exist unique value of stator voltage needed to satisfactorily operate the motor at optimum efficiency level. The proposed controller functions by manipulating the stator voltage that will maximize motor efficiency at a determined operating point. This is done by using a more energy efficient controller drive system with reduced power loses. Simulation results carried out show an improved efficiency and reduced power losses, when compared to systems without this type of controllers.
\end{abstract}

Index Terms-Electric Motors, control method, Drives, Efficiency

\section{INTRODUCTION}

The relative ruggedness and reliability of induction motors make them most useful in industries. They are generally characterized by high efficiency at their rated speed and torque though it decreases at varying loads. In order to achieve and maintain high efficiency that will result to power loss reduction and savings in energy, accurate selection of motor flux level is pertinent [1]. To improve on this, rotor flux should be reduced in such a way that it will balance both copper and core losses. Electric motors consume huge quantity of power, especially during starting. Sequel to this, a method was developed in other to improve their efficiency, thus leading to enormous savings in power and curtailment of the rate of environmental pollution, [2]. At maximum efficiency, copper loss is equal to core loss. Several control systems for induction motors with reduced losses abound in literatures [3]. Motor parameters such as input power, stator voltage, stator current, speed, flux, power factor, torque, air gap, and overall efficiency can be used to control motor systems drives [4]. In comparison with other energy optimization methods, (star mode operations, Fuzzy Logic (FL) approach, Loss Model (LM) approach etc), Search Control (SC) method enjoys some advantages such as not sensitive to variations in control parameters compared to

Omorogiuwa Eseosa, Electrical/Electronic Department, University of Port Harcourt, Choba, Nigeria, 08035150986.

Ayor Christian, Electrical/Electronic Department, University of Port Harcourt, Choba, Nigeria, 08035150986. other methods $[5,6]$. This work aims at using V/f controller to optimize energy consumption, thus saving cost via searching stator voltage values that maximizes efficiency. This will be achieved by using constant V/f ratio-based controller to optimize energy efficiency of three phase induction motor drive for industrial applications. V/f search control efficiency optimization controller has a major problem of slip increment at light load conditions, hence a slip compensator is incorporated in the V/f controller to achieve this task and still maintain normal slip value of the motor during operation. This method has an advantage over others because it is not sensitive to motor parameter changes.

Procedure for Paper Submission

\section{LITERATURE REVIEW}

Electric motors find its maximum industrial applications where mechanical energy is to be obtained from electrical energy. In most applications, they function as prime movers and are basically used to drive loads. Depending on the purpose and applications, electric motors can be used to drive pumps, fans, engines, compressors, conveyors, elevators, refrigeration system etc. No matter the application, the common characteristics of motors, is that huge amount of power requirement are required to run them. Consequently, the sudden power dip, especially during motor starting up affects other loads that are connected on the same line with the motor. There is, therefore, the need to develop and adopt energy savings/optimization in electric motor systems [7]. In our day to day industrial applications, motor driven pumps are known to have the highest consumption of electric power. This represent about twenty five percent $(25 \%)$ of the overall power consumption in United States. In Europe, it is about twenty percent (20\%) electric power consumption, [8] . One of the industrial applications of induction motors is in pump systems. They are majorly used in industries (oil, petrochemical, pulp and paper industries etc). [9]. Figure 2.0 compares energy efficient pump (connected to a drive system) and conventional pump without any built-in drive system. Investigation revealed that the conventional pump system experienced drop in efficiency because of friction and factors. [9].
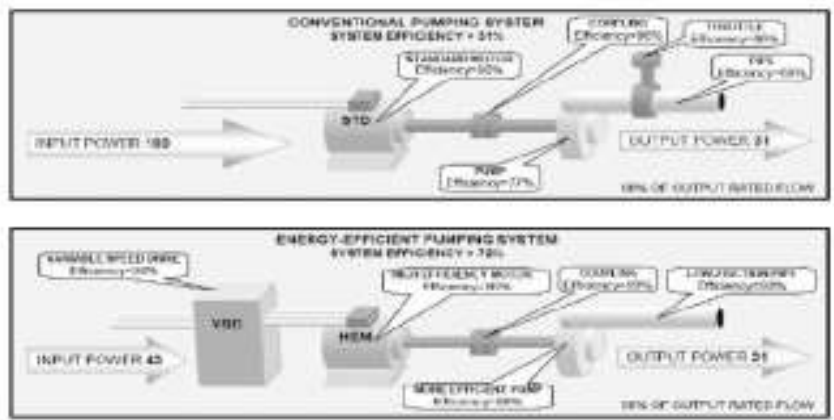

Fig 1.0: Comparison of conventional and Energy Efficient Pump System. 
In industrial applications, fans provide the required energy for HVAC systems that are needed for necessary air exchange, drying/cleaning purposes. Up to $9.5 \%$ of power consumed in industries are motor driven fans, with paper and pulp industry as high as $17.5 \%$ [10]. Fans (centrifugal or axial fans), vary in efficiency $(55 \%$ to $85 \%$ ), implying that there is still enough room for energy improvements, simply by choosing the most appropriate fan [11]. In western world, such as United States and Europe, about $10 \%$ of electrical energy is consumed by compressed air systems. [12,15,36,39]. Depending on the application, the range of compressed air systems could span from few kilowatts up to several hundred kilowatts. Compressed air use power pneumatic tools, pneumatic equipment, flushing, vacuuming, spraying etc. A typical compressed air assembly or system consists of driver (motor), compressor, filters, air receiver/tank, air distribution lines, regulating valves, check valves, oil/water separators, dryers and drain systems as shown in Figure 2.0. After production, compressed air passes through the filtration and drying units, in order to enhance its quality. All these processes contribute to appreciable overall energy losses, hence inefficiencies. According to [36], motor applications for compressed air systems have relatively low efficiencies of about $10-15 \%$. Hence, there is need for energy improvement.

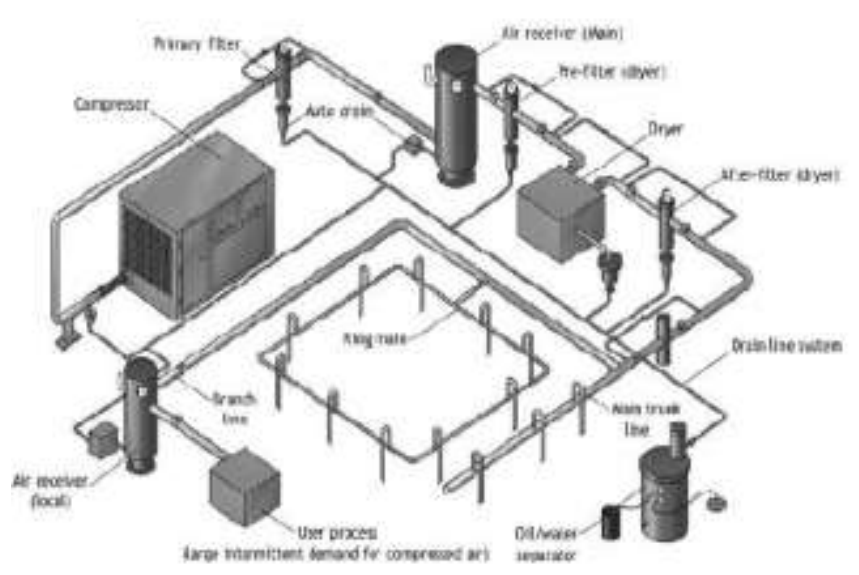

Fig 2.0: Typical compressed air system (source: Carbon Trust 2005)

Energy efficiency improvement audit conducted by the US Department of Energy and other parties, showed a tremendous improvement, with minimal payback time. These motors were used for fans, pump and compressed air systems. Others have varying degrees of payback time, depending on the investment. In some cases, as high as 50\%, [13]. Secondly, survey carried out by the same Department on the installation of 15 variable speed drives in a spinning and weaving plant in US textile industry gave rise to about $59 \%$ drop in electric power demand. Adoption and implementation of energy efficient motors have some challenges that hamper or retard its full stream. Firstly; high initial cost of purchase and installation of the drive system. Secondly; ignorance on the use and long run benefits of energy efficient technology. Thirdly; some aged motors in some industries might not be compactable to the modern drive technology. De Almeida in 1998 reveals that the process of procurement of new electric motors follows a standard process. This is another bottle-neck. Price premium placed on motors with high efficiency is another barrier. According to [15] in 2002 stated that for variable speed drives, market share import is as high as $90 \%$ due to the fact that China products lacks some special features, needed by the buyer.

Table 1.0: Motor Testing Standards

\begin{tabular}{|c|c|c|}
\hline Cosury & Institue & Standad name: \\
\hline Thitad Srates & Insidute of Elactix and Electrouc Ensinecring & EEEE 112 \\
\hline Uhitad Srates & ANST(Amarican National Standard Institute & C50.2V/Basad on IEEE 112 \\
\hline Thitad Srates & 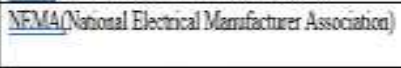 & $\begin{array}{l}\text { MGG1-12 } 28.1 \text { (Basod on IFEE } \\
\text { 112) }\end{array}$ \\
\hline Canais & Canadian Standards Assocision & C-39N-M1985 \\
\hline Japas & Japen Elactrotechnical Committer & $\mathrm{JEC}-37$ \\
\hline Geat Bntain & Bitish Stendard & BS-269 \\
\hline Japan & Intemorional Elactustectrical Commissina & ECC.34-2 \\
\hline
\end{tabular}

Institute of Electrical and Electronic Engineers (IEEE) 112 standard recognizes three main methods for determining motor efficiency, namely (1) Method A, simple input-output (2) IEEE 112 Standard Method B, input-output with loss segregation (or separation) (3) IEEE 112 Standard Method F, equivalent circuit (model) calculation. IEEE 112 Standard Method B estimates the efficiency by the direct method. Stepwise procedures on how the testing is to be carried out while at full operating temperature is also detailed by this method.

The IEC 34-2 Standard provides several procedures and methods for measurement of efficiency in accordance with the type and sizes of machine, with appropriate accuracy, etc. These methods can be subdivided in two categories: (1) "direct" method: the absorbed and provided power at the motor shaft is directly measured; and (2) the "indirect" method: the motor losses are measured by suitable tests and the efficiency is measured by measuring the motor adsorbed power. The CSA C390 Method 1 test standard is equivalent to IEEE 112 Method B test standard and it is commonly used in Canada. Summarily, IEEE 112, IEC 34-2 and JEC 37 are more widely accepted standards. Notwithstanding, measurement of efficiency could differ in value worldwide, because of various standards used. [18, 19, 20, 21]. However not all users are able to understand and use them easily even if these standards exist. The government is considered to play the best role in managing standards since it can protect all users including manufacturers, industries and public. As a result, the efficiency tables endorsed by government agencies are the most important and mostly referred. The policy has set that motors having efficiencies equal to or higher than EPAct is designated as Energy Efficient and considered as standard. In further development, NEMA has issued an efficiency reference table of higher values than efficiency table provided by EPAct and thus, defining the minimum nominal efficiency for NEMA Premium TM Efficiency Motor Program [21].

Table 2.0: Shows difference between two NEMA standards of induction motors, standard efficiency and premium efficiency.

\begin{tabular}{|c|c|c|c|c|c|c|c|}
\hline$\$ N$ & Botsepower & $\begin{array}{l}\text { Standard } \\
\text { Efficien? }\end{array}$ & $\begin{array}{l}\text { Premium } \\
\text { Efficiency }\end{array}$ & $\mathbf{S N}$ & Hotsepower & $\begin{array}{l}\text { Staodand } \\
\text { Efficiency }\end{array}$ & $\begin{array}{l}\text { Premaun } \\
\text { Effrieacy }\end{array}$ \\
\hline 1 & 780 & 82.5 & 8 & 6 & 25 & 902 & 930 \\
\hline 2 & 785 & 80 & 50 & 7 & 50 & $9 ! .7$ & 941 \\
\hline 3 & 50 & 8.6 & 100 & 8 & 100 & 91.7 & 950 \\
\hline 4 & 140 & 91.1 & 250 & 9 & 290 & 94.1 & 958 \\
\hline 5 & 575 & 91.7 & & & & & \\
\hline
\end{tabular}


Obviously from Table 2.0, using standard motor will improve energy consumption. On the other hand, use of premium efficiency motors will give rise to better efficiency improvement. More so, larger motors have higher efficiency compared to small motors $(<10 \mathrm{~kW})$. The speed of the motor is given by,

Speed $(\mathrm{rpm})=$ Frequency $($ hertz $) \times 120 /$ No. of Poles

Efficiency optimization technique concludes that induction motors operate with rated value of flux for rated load torque. If the load torque is less than rated torque, efficiency will be improved, since less torque implies reduced flux, hence reduction in core losses. Up to about $15 \%$ of energy saving can be achieved. Various controller types used for motor operation with minimal operating energy cost at partial load, was investigated [36 ].

LM Controllers manipulates and computes total losses and precisely select the level of flux that will minimize losses. This is done by measuring the stator current and rotor speed and using the result to compute the optimal flux level. Since minimum loss implies improved energy efficiency, hence energy efficiency is optimized. The major limitation of this method is that, exact values of machine parameters are needed for computation. [37,38]. But computations involving power loss modeling of optimal operating conditions could be very complex and tedious. In Search Controller for Minimum Input Power, electrical input power of the machine drive is measured regularly at defined intervals. The controller therefore, searches for flux value that gives rise to minimum power input for given values of speed and torque. This method has limitation, in the sense that it is slow to reach the optimum value. Also, there are ripples in steady state torque. This type of control is independent of the variations in motor parameters [32]. Optimal Control of Induction Motor through Search Control (SC) functions by: (i) Carrying out direct measurement of motor drive input power at regular interval. (ii) The controller carries out search on optimal flux level that will search optimal flux value that yield minimum input power or stator current for the given values of speed and torque. The main advantages of search control efficiency optimization method include: Savings in power is not limited to the motor alone, but the entire system, reduction of the total energy consumed, power measurements is much easier and accurate to obtain, because current waveforms and applied voltage have relatively smaller harmonic contents than that of the corresponding motor waveforms and this type of control is independent of motor parameters and it is not sensitive to changes in motor parameters. FL controller works on an aggregation of rules. These rules are based on conditions of input variables and the corresponding desired outputs. This controller converges flux smoother and faster under certain operating conditions, to the values that will give minimum power loss and can handle non-linearities that are very difficult to model. Special interests are needed towards continuous improvements in motor standards for efficiency enhancement. This should be the major area of interest to both researchers and industries. However, until today there is no single and acceptable standard method of measuring motor's efficiency used throughout the industry [18]. For example, in the area of electric motors, total cost of purchase was used as a key factor in determining quality or standard, especially in motors that are less than 250 Horsepower. In other standards, motor performance was used. In this case, minimum active material was used to increase motor performance, [23]. Another standard focuses on optimum temperature controls, [24]. The exploration and improvement of the study of those standards found that efficiency is the first and most important parameter, because, performance and cost are functions of efficiency. These standards are used by the industries as reference points, [25,26,27,28]. Among the common standards are shown in Table 2.0. Also, increase in temperature, (as low as $4^{\circ} \mathrm{C}$ rise) can result in great change in stator and rotor resistance. This will consequently lead to poor motor performance and its drive system [29,30,31]. When the motor is at high speed, the stator resistances drop. However, at low speeds, this drop becomes dominant compared to input stator voltage. Consequently, this lead to the introduction of errors, while estimating of stator flux [32]. As rotor temperature increases, rotor resistance also increases. This will lead to decrease in slope of torque-speed curve. Hence, the operating point will shift, leading to a reduced efficiency $[33,34]$. Therefore, improvement has to be made on rotor flux-estimator in other to minimize the effect of the stator-resistance, especially, while calculating rotor flux at standstill [35]. Obviously, since thermal effect has undesirable effect on drive systems, the improvement of thermal design methodology of induction motor should be considered.

\section{RESEARCH METHODOLOGY}

The research method includes the following:

$>$ Design of induction motor drive system operating without any controller

$>$ Design of efficiency optimization controller with slip compensation incorporated in it

$>$ Design of efficiency optimized drive system with slip compensation.

This is achieved with the aid of MATLAB Simulink. Mathematical description of the design is analyzed. The drive systems in this work consist of three-phase induction motor incorporated with $V / f$ controller. For effective analyses of the system performance, all these components were modelled, as described, mathematically.

\section{A. Design of Induction Motor Drive System Operating without any Controller}

In this design, the first stage is to feed the motor input directly by a normal voltage source. The second part of the drive system is the induction motor design. The name plate data of an existing motor from Sneider electric for external cooling and ventilation system application in Shell Belema gas plant was obtained and used for simulation of the drive system (See Table 3.0). The motor was originally designed with flux linkages and voltage equations describing the model of squirrel cage induction motor with respect to d-q coordinates. Modeling and design of drive system operating without controller in MATLAB/SIMULINK environment is shown in Figure 3.0 
Table 3.0: Induction Motor Data (Source: Sneider Electric Motors)

\begin{tabular}{|c|c|}
\hline Stator resistanse $R_{1}$ & 1.2909 \\
\hline Statar Inductance $L_{\text {f }}$ & $0.006 \%$ \\
\hline Mutual Indusctarve $L_{m}$ & $1.172 \mathrm{H}$ \\
\hline Retor rexistance tefented to the utator $R_{f}$ & $1395 \Omega$ \\
\hline Rotor Inductance referred to the stutor $L_{2}$ & $0.006 \mathrm{H}$ \\
\hline Nominal valtage $E_{c}$ & $230400 \mathrm{~V}$ \\
\hline Nominal sorpux power $E$. & $4 \mathrm{~kW}$ \\
\hline Naminal power factar casd. & 0850 \\
\hline Nemsinal frtiguency $\&$ & $50 \mathrm{~Hz}$ \\
\hline Number of poles $P$ & 4 \\
\hline Nommal totational speed $n_{t}$ & $1430 \operatorname{mpm}$ \\
\hline Moneent of inertia $f$ & $0.0132 \mathrm{~kg} \mathrm{~m}^{2}$ \\
\hline
\end{tabular}

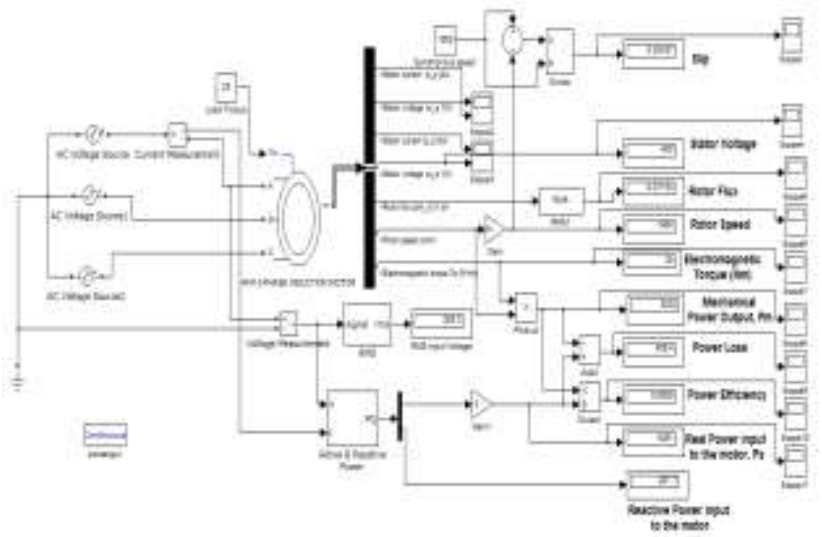

Figure 3.0: Modeling and Design of Drive System Operating Without Controller in MATLAB/SIMULINK

The other part of the design shows detailed mathematical computations of slip, synchronous speed, input and output power as well as losses and efficiency. These are shown from equations [2] to [7]

Synchronous speed $N_{S}$ : The synchronous speed of the motor is defined mathematically as:

$N_{S}=\frac{120 \times f}{P}=\frac{120 \times 50}{4}=1500 \mathrm{rpm}$

Where $\mathrm{P}$ is the number of poles and $\mathrm{f}$ is the frequency.

Slip, S: Slip is mathematically defined as:

$S=\frac{N_{S}-N_{r}}{N_{S}}$

Input power, $P_{S}=I \times V \times \cos \emptyset$

where $\mathrm{I}$ is the input current supply, $\mathrm{V}$ is the voltage supply and $\cos \emptyset$ is the supply power factor.

Output power, $P_{m}=T e \times \omega_{r}$

Where $T e$ is the Electromagnetic Torque in Newton-meter and $\omega_{r}$ is the rotor angular speed radian per second.

Power loss, $P_{\text {loss }}=P_{s}-P_{m}$

Where $P_{s}$ the input is power to the motor and $P_{m}$ is the mechanical output power of the motor.

Efficiency, $\boldsymbol{\eta}$ : This is ratio of motor mechanical output power to the input power supplied.

$\eta=\frac{P_{m}}{P_{s}}$

\section{B. Design of Efficiency Optimization Controller}

The efficiency optimization controller is designed based on Search Control (SC) method. This involves construction of matrix as shown in Table 3.3. This matrix consists of optimal values of stator voltages, frequencies and loads and its constructed using MATLAB/Simulink model of the drive system parameters to maximize the motor efficiency. A 2D lookup module in MATLAB was formed using the matrix of Table 3.3 since its an important part of the proposed efficiency optimization controller, as shown in Fig 3.2 and Fig 3.3 respectively. The controller is modelled such that after the search is done on the voltage matrix in the lookup module, an optimized stator voltage is selected and divided by the nominal voltage of the system. Modulation index, $\mathrm{m}$ is the final output of the controller. The value of $m$ determines the optimal voltage value that will maximize the efficiency under specified operating conditions. V/f controllers normally consist of IGBT inverter (DC-AC converters). The value of $m$ normally ranges from 0 to 1 . The actual stator voltage $V_{S}$ is defined as:

$V_{s}=m V_{n}$

Where $V_{n}$ is the nominal value of the stator voltage

Stator voltage frequency $=$ sinusoidal input waveform frequency:

$f=f_{\text {in }}$

Equations [8] and [9] constitute the steady state model of the V/f controller similar to that of an inverter. Thus, variations in $\mathrm{m}$ and sinusoidal frequency waveform will automatically lead to changes in RMS values of the stator voltages and frequencies respectively.

For $0<f<f_{n}$

Then $m=K f$

Else for $f \geq f_{n}$, Then $\mathrm{m}=1$

Where

$K=1 / f_{n}$

$f_{n}$ is nominal frequency. This V/f controller is modeled based on equations [7] to [11]. The block diagram is represented as shown in Figure 4.0.

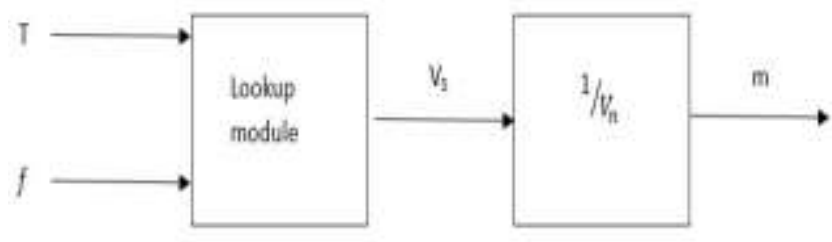

Fig 4.0: Block diagram of Efficiency optimization controller.

Table 4.0: Optimal Voltage, Depending on Frequency and Load Torque Variations.

\begin{tabular}{|c|c|c|c|c|c|c|}
\hline \multirow[b]{2}{*}{ Voltage, V } & \multicolumn{6}{|c|}{ Losd Toryte, (Nm) } \\
\hline & & 5 & 10 & 15 & D & 25 \\
\hline \multirow{10}{*}{ Frequensy, $(\mathrm{Hz} z)$} & \multirow{10}{*}{$\begin{array}{l}5 \\
10 \\
1 \\
2 \\
2 \\
30 \\
35 \\
4 \\
4 \\
5\end{array}$} & 328 & 26.4 & 57.6 & 656 & 73.6 \\
\hline & & 584 & 86.4 & 100 & 116 & 130.4 \\
\hline & & 83.2 & 116 & 1432 & 176 & 190.4 \\
\hline & & 109.6 & [5L] & 1556 & 280 & 246.4 \\
\hline & & 137.6 & 196.8 & 2368 & 267.2 & 3888 \\
\hline & & 160.8 & 2224 & 2728 & 324 & 3496 \\
\hline & & 199.6 & 296.8 & 326.4 & 369.6 & 400 \\
\hline & & 200.8 & 2952 & 3536 & 40 & 400 \\
\hline & & 243. & 30 & 3912 & 400 & 400 \\
\hline & & 2728 & 3728 & 400 & 400 & 400 \\
\hline
\end{tabular}




\section{Design of Drive System with V/f Controller plus Slip Compensation}

This section shows complete drive system operating with V/f controller having slip compensator incorporated in it. The controller output is fed into a controlled voltage source before it is fed into the motor. Simulation results from previous works done on this topic revealed that the main demerit of this method was slip increase, mainly during low frequencies and at light loads. To overcome this, a slip compensator is added in accordance to some reference values $\mathrm{S}_{\text {refs. }}$. To achieve this, the motor torque must be increased, by increasing the optimized system stator voltage. The slip error will be gained and integrated in other to determine the compensation voltage to be added to that of the existing system. At steady state, operating point efficiency is determined using equation [6]. Although the total input power to the stator is modelled in terms of equation 12]

$P_{s}=\frac{3}{2}\left(V_{s d} I_{s d}+V_{s q} I_{s q}\right)$

The compensation voltage $V_{\text {com }}$ is determined by using equation [13]

$V_{\text {com }}=K_{i} \int\left(S_{\text {ref }}-S\right) d t$

Where $\boldsymbol{K}_{\boldsymbol{i}}$ is the integrating factor. Equation 13 is achieved by adding an integrator as a feedback loop into the optimization controller. The complete diagram of the drive system with V/f controller is shown in figure 5.0

Fig 5.0: Simulink diagram of the drive system with

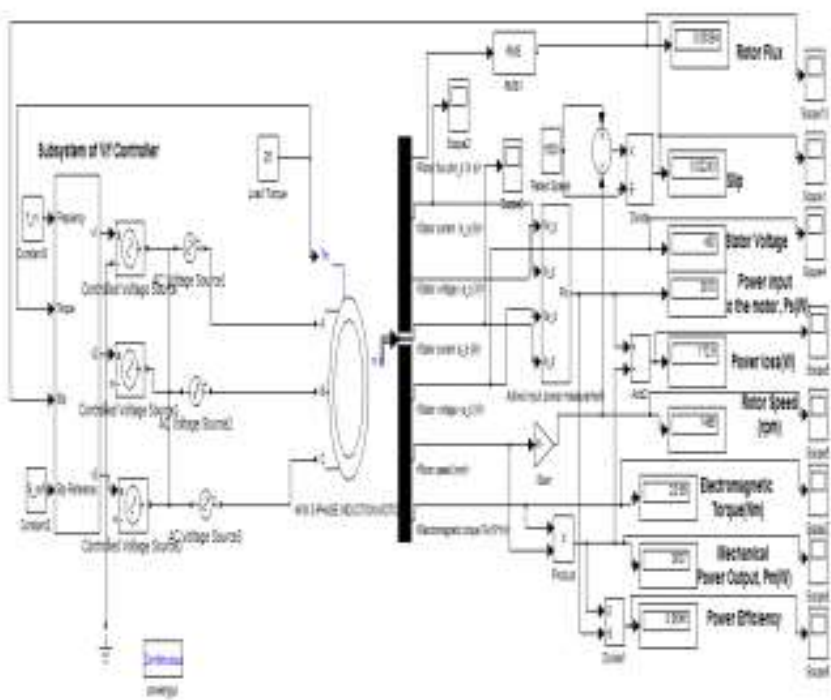

Efficiency optimization controller plus slip compensation

\section{RESULT ANALYSIS AND DISCUSSION}

Table 5.0 presents the result of the system operating without voltage controller and slip compensator while table 4.2 presents result of the induction motor drive when it is incorporated with V/f controller and slip compensator. The results are measured in terms of Slip, Rotor Flux, Input Power, Rotor Speed, Electro-magnetic Torque, Power Output and Overall Efficiency.
Table 5.0: Results of drive system without any controller.

\begin{tabular}{|c|c|c|c|c|c|c|c|c|}
\hline $\begin{array}{l}\text { Lead } \\
\text { Terque } \\
(\mathrm{Nm})\end{array}$ & sip & $\begin{array}{l}\text { Bebar } \\
\text { Flus }\end{array}$ & $\begin{array}{l}\text { Hoter } \\
\text { Speed } \\
\text { (rppin) }\end{array}$ & $\begin{array}{l}\text { Vlectr: } \\
\text { magaeti: } \\
\text { Torqu } \\
\text { (Nm) }\end{array}$ & $\begin{array}{l}\text { laput } \\
\text { Pewer (w) }\end{array}$ & $\begin{array}{l}\text { Ouiput } \\
\text { Pewer } \\
\text { (w) }\end{array}$ & $\begin{array}{l}\text { Power } \\
\text { Laes } \\
\text { (w) }\end{array}$ & $\begin{array}{l}\text { Kmaken } \\
\text { or u) }\end{array}$ \\
\hline 5 & 6.004654 & Q.0104k & 1490 & 5 & 863.4 & 781.7 & I165 & 0.9054 \\
\hline 10 & 60094 & 0.02572 & 1485 & 15 & 16648 & 1556 & 132.3 & 09216 \\
\hline 15 & 0.01425 & 0.048 & $14 \%$ & is & 2425 & 1523 & 2024 & $0.957 \%$ \\
\hline 20 & 6.5192 & 0.05627 & 1471 & 26 & 3359 & 3001 & 277.8 & 0.9173 \\
\hline 24 & 6.02427 & a.fis4 & 1464 & 29 & $A \geq 1$ & 3892 & 450.4 & $0 \times 029$ \\
\hline
\end{tabular}

The result presented in Table 5.0, depict relationship between efficiency and other motor parameter at different load torque for an induction motor drive operating without any ideal controller. The result shows that, at an increasing load Torque of an induction motor up to its full load condition, speed decreases. The result also shows that as load increases, the motor draws more power to drive the load, hence the mechanical output power loss due to loading increases. The result also shows that load Torque is a direct proportionate function of Rotor Slip. The table further explained that at an increasing loading, the motor speed under normal operating condition will experience sudden speed decrements. The decrease in speed is as a result of reduced rotor current and stator flux. More so, at increasing load, the motor is forced to draw more power to rotate the system, hence resulting into high mechanical output power loss. It also explains that at high slip, efficiency will drop due to increase loading and consequent reduced speed. Relationship between motor efficiency and load Torque is established. And that motor efficiency normally reduces at light loads and increases up to full load but tends to reduce at values above rated maximum Torque.

Table 6.0: Results of Drive System With v/f Controller + Slip Compensator

\begin{tabular}{|c|c|c|c|c|c|c|c|c|}
\hline $\begin{array}{l}\text { Lasd } \\
\text { Torquet } \\
\text { (Nit) }\end{array}$ & STp & $\begin{array}{l}\text { Roter } \\
\text { Flux }\end{array}$ & $\begin{array}{l}\text { Rotur } \\
\text { Speed } \\
\text { (ppm) }\end{array}$ & $\begin{array}{l}\text { Electr: } \\
\text { magartic } \\
\text { Torye (Niii) }\end{array}$ & $\begin{array}{l}\text { laput } \\
\text { Pouter } \\
\text { (v) }\end{array}$ & $\begin{array}{l}\text { Outpat } \\
\text { Poutr } \\
\text { (iv) }\end{array}$ & $\begin{array}{l}\text { Poner } \\
\text { Lass } \\
\text { (w) }\end{array}$ & $\begin{array}{l}\text { Efficiency } \\
\text { (p.s) }\end{array}$ \\
\hline 5 & 0.00774 & $00206 ?$ & 1458 & 6.814 & 100 & $100 ?$ & 1589 & 0.9553 \\
\hline 10 & Q.6054L2 & $0.555 ?$ & 1492 & 8.24 & 1319 & 1295 & $23.8 ?$ & 09521 \\
\hline 15 & 0.01365 & $0.04^{7} 5 ?$ & 1472 & 15.74 & 2510 & 2428 & 82.12 & 09693 \\
\hline 20 & 0,01542 & 0.05718 & $14 \pi$ & 2083 & 334 & 322 & 1266 & 0952 \\
\hline 8 & 0.02213 & 0.06394 & 1466 & 2569 & 3510 & 3637 & 1729 & 09546 \\
\hline
\end{tabular}

Table 6.0 shows various relationships between motor efficiency and other motor characteristic properties. These are measured in terms of Slip, Load Torque, Speed Input and Output Power. From Table 4.2, efficiency decreases with increase in Load Torque. Speed also decreases with loading. Rotor Flux increases with loading hence slip does increase likewise. Input and Output power increases but with very slight proportionate difference (losses). The results obtained agreed with normal operating characteristics of induction motor. 
Comparison of both systems was also analyzed with respect to power flow, losses and efficiency as shown in Tables 7 and 8. Table 7.0 analyses the motor when its operating without any energy efficient controller while Table 8.0 shows when the system is operating with an energy efficient controller whose output is a controlled stator voltage used to minimize flux imbalance and improve power efficiency.

Table 7.0: Comparison of Both Drive Systems motor without v/f controller plus slip compensator

\begin{tabular}{|c|c|c|c|c|c|c|}
\hline $\begin{array}{l}\text { Lead Torque } \\
\text { (Nis) }\end{array}$ & $\begin{array}{l}\text { Pewer Los } \\
\text { (W) }\end{array}$ & $\begin{array}{l}\text { Electro- } \\
\text { magentic } \\
\text { Torque (Nw) }\end{array}$ & $\begin{array}{l}\text { E.flickac } \\
\text { (p.w) }\end{array}$ & Sap & $\begin{array}{l}\text { Rator fles } \\
\text { (Whan) }\end{array}$ & $\begin{array}{r}\text { Rotar Spend } \\
\text { (rpwi) }\end{array}$ \\
\hline 5 & 5165 & 5 & 090 & 0.004 & 0.01 & 1499 \\
\hline 10 & 1323 & 10 & 0.92 & 0.000 & 0.02 & 1485 \\
\hline 15 & 1024 & 15 & 0.95 & 0.014 & 0.84 & 1470 \\
\hline 20 & 2773 & 20 & 0.91 & 6.019 & 0.05 & $14 \pi$ \\
\hline 25 & $459 \mathrm{~A}$ & 25 & 089 & 0,24 & 0.07 & 464 \\
\hline
\end{tabular}

Table 8.0: Comparison of Both Drive Systems motor with v/f controller plus slip compensator

\begin{tabular}{|c|c|c|c|c|c|c|}
\hline $\begin{array}{l}\text { Load } \\
\text { Iorque } \\
\text { (Vn) }\end{array}$ & $\begin{array}{l}\text { Pouer Loss } \\
\text { (W) }\end{array}$ & $\begin{array}{l}\text { Electre- } \\
\text { magaetik } \\
\text { Torq̨at }\left(\mathrm{S}_{\text {Nin) }}\right.\end{array}$ & $\begin{array}{l}\text { Emideacy } \\
\text { (p. p) }\end{array}$ & Slip & $\begin{array}{l}\text { Rotur Flex } \\
\text { (Wbine) }\end{array}$ & $\begin{array}{l}\text { Rator Speed } \\
\text { (rpm) }\end{array}$ \\
\hline 5 & 15.89 & 6.514 & $09 \mathrm{t}$ & 0.007 & 0.02 & 1488 \\
\hline 10 & 23.62 & 1.294 & 094 & 0,005 & 0.02 & 1492 \\
\hline 15 & 82.12 & 15.74 & 097 & 0.018 & 0.05 & 1472 \\
\hline 20 & 126.6 & 20.83 & 0.96 & 0.015 & 0.06 & 147 \\
\hline 25 & 1729 & 23.65 & 0.95 & 0.022 & 0.07 & 1466 \\
\hline
\end{tabular}

Considering the drive system efficiency without V/f controller and slip compensator, the efficiency is about 0.90 p. $u(90 \%)$ at load Torque of $5(\mathrm{Nm})$ while the optimized system with $v / f$ controller has $0.98 p$. $u$ ( $98 \%$ efficiency) at same load Torque. At $25(\mathrm{Nm})$ load Torque, the non-optimized system has efficiency of about 0.89 p.u (89\% efficiency) while that of the optimized system has about $95 \%$ efficiency. The same trend is observed at different load Torque. The efficiency of the optimized system becomes more improved than at its normal operating behavior. The reason for such increase (improvement) in efficiency is a confirmation of the research procedure. The research procedure posits that the search method for the proposed controller will choose a single and optimal value of stator voltage to improve efficiency at different load Torque and frequency. Evidently, Tables 7 and 8 indicates that the balance between rotor flux is achieved as electro-magnetic torque is improved, hence maintaining motor speed. This causes power balance between input and output power thereby reducing power loss and improving efficiency. As mentioned earlier, $v / f$ controller causes abrupt slip increment at light loads. The slip for non-compensated system is $0.004(0.04 \%) 5(\mathrm{Nm})$ load, but consequently maintained at $0.007(0.7 \%)$ at same $5(\mathrm{Nm})$ load for the slip compensated system, hence the motor speed is maintained even as the efficiency is optimized due to rotor flux balancing and electromagnetic torque influence on the rotor. It can also be seen from the table that the slip at larger loads is more reduced in the energy efficiency optimized system than the ordinary drive system. This shows that slip compensator will maintain slip value at certain threshold even at the process of achieving power balance and efficiency optimization using search technique-based V/f controller. It is thus, believed that if such industrial applications requiring, the use of energy efficient motors adopts this standard of optimizing efficiency, more energy would be saved, because of improved power efficiency and minimized power loss.

Fig 6.0 shows output power waveform drive system without controller while Fig 7.0 shows Power output waveform of a drive system with energy efficient controller. Furthermore Fig.8.0 describes power loss waveform of drive system without controller while Fig 9.0 shows power loss waveform of a drive system with energy efficient controller. Efficiency waveform of a drive system without a controller and with energy efficient controller is shown both in Fig 10.0 and 11.0respectively. The input power of a drive system without controller is shown in Fig 12.0.

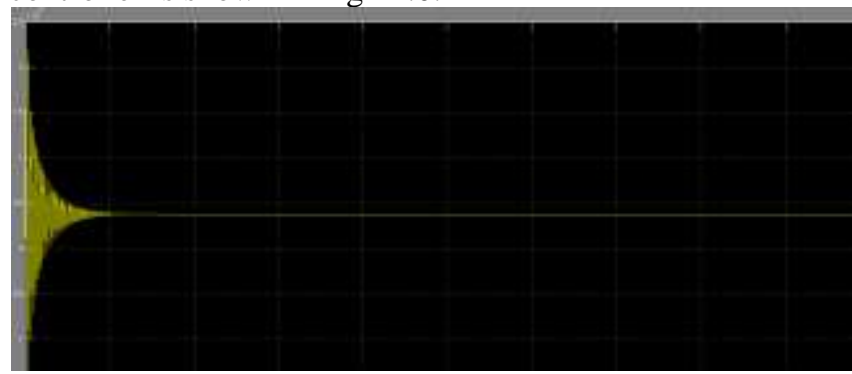

Fig 6.0: Output power waveform drive system without controller.

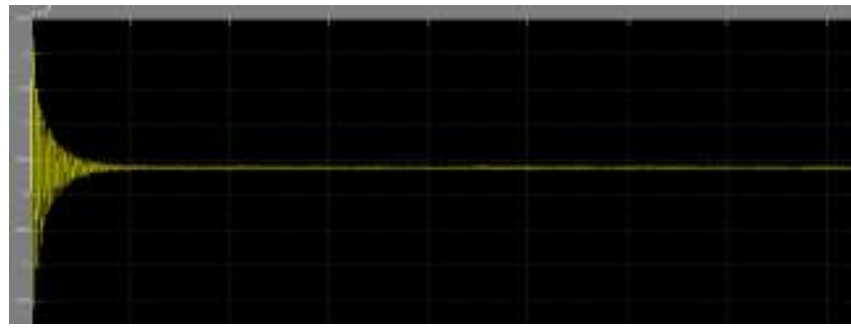

Fig 7.0: Power output waveform of a drive system with energy efficient controller

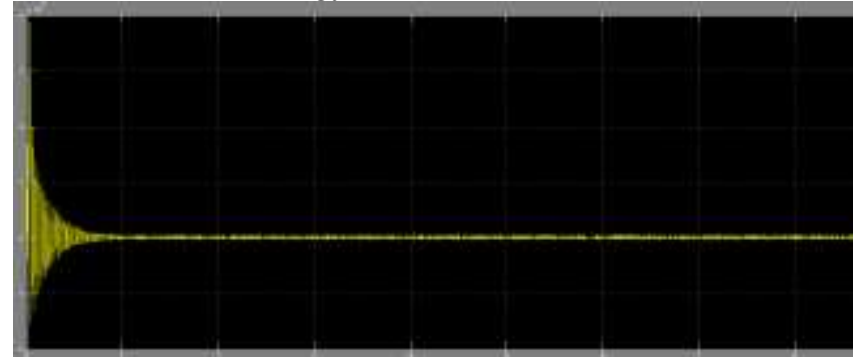

Fig 8.0: Power loss waveform of drive system without controller.

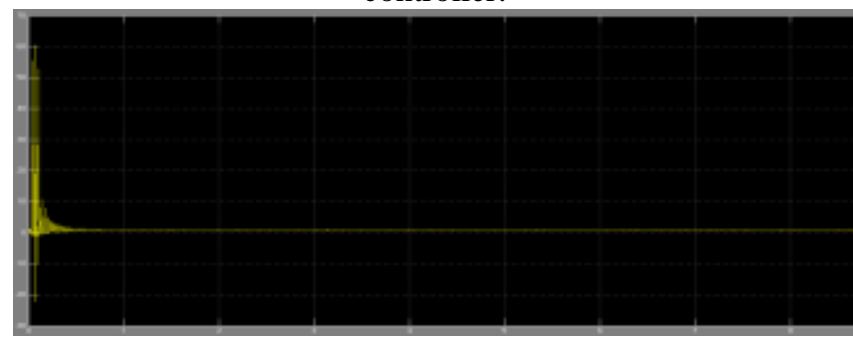

Fig 9.0: Efficiency waveform of a drive system without a controller. 


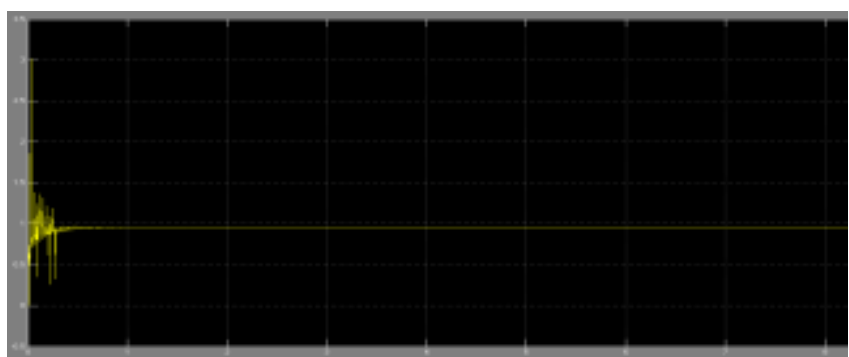

Fig 10.0: Efficiency waveform of drive system with energy efficient controller

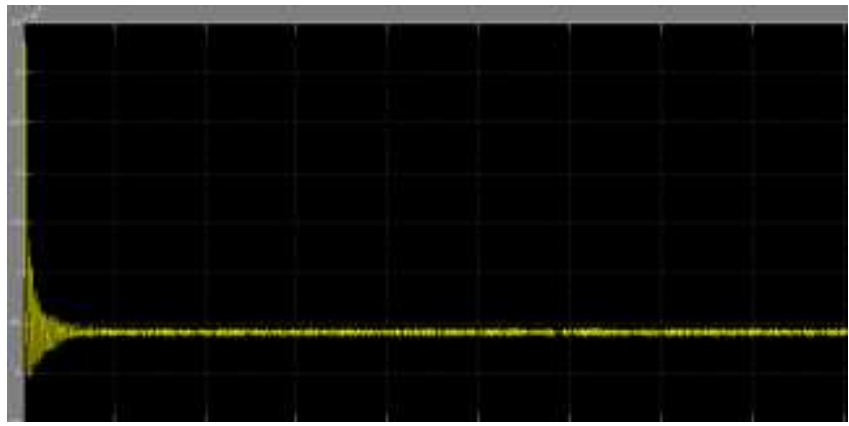

Fig 11.0: Input power of a drive system without controller

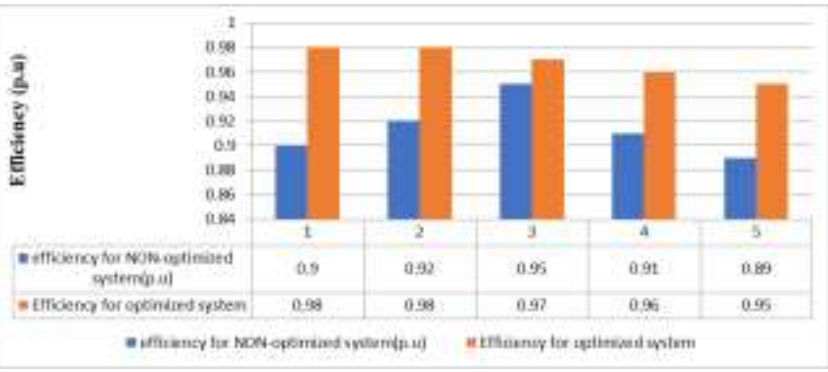

Fig 12.0: Comparison of efficiency for both drive systems

\section{CONCLUSION}

In this research work, an efficient optimization controller, based on search control method is developed. The controller's main task is to monitor input power to the motor and selects optimal flux value that will give rise to minimum power input or stator current at specified values of torque. The controller manipulates value of stator voltage that will maximize motor efficiency at specified operating points. The controller also minimizes loses by ensuring that iron and copper losses are balanced, hence minimizes power losses and improve efficiency of the system. Since slip increment is a major problem associated with the search method. A slip compensator has been added to the controller, in other to reduce the slip to an acceptable value. The work is only limited to three phase electric drives having variable load and frequency applications. In this paper, a search controller that will optimize efficiency of motor drive is developed. It searches stator voltage value to maximize motor efficiency. The system is simulated, and analysis of results was presented while considering incorporating slip compensator in other to minimize the effect of slip mainly at light loads and low frequencies. This is achieved by modeling and comparing efficiency of drive system with and without V/f controller. An efficient optimization controller based on search method has been developed. The proposed controller functions by manipulating the stator voltage that will maximize motor efficiency at a determined operating point. To minimize slip effect to an acceptable level, slip compensator was added to the system. From the results, light loads and high frequencies favoured the optimized system. This is because at $50 \mathrm{~Hz}$ frequency, the motor uses $400 \mathrm{~V}$ stator voltage to perform efficiency optimization at load torque of $5 \mathrm{Nm}$. The efficiency cannot be improved if there is no power balance between input and output. As it is shown in tables 4.1, 4.2 and 4.3 respectively, the input to output power is much balanced for the optimized system than that of the normal drive system hence power loss is more reduced in the optimized system than that of the normal system. Concluding evidence is that electromagnetic torque is much more developed, and the rotor flux is much balanced in the optimized system, thus leading to moderate operating speed within its normal operating characteristics. Although slip increment is an abrupt disadvantage of $\mathrm{V} / \mathrm{f}$ controller, the slip compensator having a slip reference of about $4 \%$ helped maintain motor slip irrespective of changing electromagnetic torque that would have caused change in slip.

\section{RECOMMENDATION}

This paper showed clear evidence that induction motors used in drive systems usually have low efficiency at light loads. This efficiency can thus be improved with the use of a controller that will help maintain power balance at changing flux, hence reducing losses and improving efficiency. It is therefore recommended that induction motors drive systems should be properly modelled with V/f controller based on search method in order to achieve a more energy efficient drive system and low power and energy losses. Special interests are needed towards continuous improvements in motor standards for efficiency enhancement. This should be the major area of interest to both researchers and industries. However, until today there is no single and acceptable standard method of measuring motor's efficiency used throughout the industry

\section{REFERENCES}

[1] H. R. Andersen, C. B. Rasmussen, E. Ritchie and J. K. Pedersen, "Efficiency Comparison of Electrical Motors for Energy Optimized Variable Speed Low Power and Low Cost Household Equipment," 6th European Conference on Power Electronics and Applications, Seville, 1995, pp. 3381-3386.

[2].W. Leonhard, "Controlled AC Drives, a Successful Transfer from Ideas to Industrial Practice," Control Engineering Practice, Vol. 4, No. 7, 1996, pp. 897-908.

[3] F. C. Lin and S. M. Yang, "On-Line Tuning of an Efficiency-Optimized Vector Controlled Induction Motor Drive," Tamkang Journal of Science and Engineering, Vol. 6, No. 2, 2003, pp. 103-110.

[4] A.K. Sharma, R. A. Gupta and Laxmi Srivastava. "Im-plementation of Neural Network in Energy Saving of In-duction Motor Drives with Indirect Vector Control," Journal of Theoritical and Applied Information Technol-ogy, Vol. 5, 2008, pp. 774-779.

[5]. F. Abrahamsen et al., "Efficiency-Optimized Control of Medium-Size Induction Motor Drives," IEEE Transac-tions on Industry Applications, Vol. 37, No. 6, 2001, pp. 1761-1767. doi:10.1109/28.968189

[6]. A. Ansari and D. M. Deshpande, "Induction Motor Efficiency Optimization Using Fuzzy Logic," International Journal of Advanced Engineering and Applications, Vol. 1, 2010, pp. 177-180.

[7]. Brunner, C.; Borg, N.; (2009): From voluntary to mandatory: policy developments in electric motors between 2005 and 2009: Beitrag auf der eceee 2009.

[8]. ETSU; CETIM; D.T.Reeves; NESA; Technical University Darmstadt (2001): Study on improving the energy efficiency of pumps, Brussel: European Commission.

[9].Elliot, R.N.; Nadel, S. (2003): Realizing Energy Efficiency Opportunities in Industrial Fan and Pump Systems, Washington D.C. American Council for an Energy-Efficienct Economy. 
[10]. Radgen, P. (2002): Market study for improving energy efficiency for fans, Stuttgart: FraunhoferIRBVerl.

[11]. Radgen, P.; Oberschmidt, J.; Corry, W.T.W. (2007): EuP Lot 11: Fans for ventilation in non residential buildings, Karlsruhe.

[12]De Keulenaer H.; Belmans R.; Blaustein E.; Chapman D.; De Almeida A.; De WachterB.Radgen P. (2004): Energy Efficient Motor Driven Systems ... can save Europe 200 billion kWh of electricity consumption and 100 million tonne of greenhouse gas emissions a year, Motor Challenge, Brussels: $\quad$ European Copper Institute.doi:10.1016/0967-0661(96)00087-1

[13]. Peters, J.; Nadel, S. (2004): China Motor System Energy Conservation Project: Second Process Evaluation, Vienna: UNIDO.

[14]. De-Almeida, A.T.; Ferreira, F.; Fong, J.; Fonseca, P. (2008): EUP Lot 11 Motors, Preparatory study for the Energy Using Products (EuP) Directive, Coimbra.

[15]. Nadel, S.; Wanxing, W.; Liu, P.; McKane, A. (2002): The China Motor Systems Energy Conservation Program: A Major National Initiative to Reduce Motor System Energy Use in China.

[16]. IEA (2007): Tracking Industrial Energy Efficiency and CO2 Emissions, Paris: International Energy Agency (IEA).

[17]De Almeida, E. (1998): Energy efficiency and the limits of market forces: The example of the electric motor market in France. In: Energy Policy, 26 (8), pp. 643-653.

[18]. Renier B, Hameyer K, Belmans R (1999). Comparison of Standards For Determining Efficiency Of Three Phase Induction Motors, IEEE Trans. Energy Conversion, 14(3): 512-517.

[19] Lu B, Habetler TG, Harley RG, Thomas GH, Ronald GH (2006). Solving Induction Motor Equivalent Circuit using Numerical Methods for an In-Service and Nonintrusive Motor Efficiency Estimation Method, IPEMC, pp. 1-4.

[20]. S. M. Yang and F. C. Lin, "Loss-Minimization Control of Vector-Controlled Induction Motor Drives," Journal of the Chinese Institute of Engineers, Vol. 26, No. 1, 2003, pp. 37-45. doi:10.1080/02533839.2003.9670752

[21]. Agamloh EB (2009). A Comparison of Direct and Indirect Measurement of Induction Motor Efficiency, IEEE Electric Machines and Drives Conf., pp. 36-42.

[22]. MahanteshGutti; Manish G Ratti; JagadishPatil (2014): Efficiency optimization of induction motors drives using PWM technique. Pg 19.

[23]. Tessarolo A, Giulivo D, Mezzarobba M (2009). A System-Level Approach To The Optimal Dimensioning Of Induction-Motor Variable-Frequency Drives, 13th European Conf. Power Electron. Appl., pp. 1-10.

[24]. Khalifa FA, Serry S, Ismail MM, Elhady B (2009). Effect of Temperature Rise on the Performance of Induction Motors Int. Conf. Comput. Eng. Syst., pp. 549-552.

[25]. Cummings PG, Bowers WD, Martiny, WJ (1981). Induction Motor Efficiency Test Methods, IEEE Trans. Ind. Appl., (3): 257-272.

[26]. Doppelbauer, M.; Kirtley, J.L.; Peters, D.T.; Brush, E.F. (2005): Performance Characteristics ofDriver Motors Optimized for Die-cast Copper Cages: Beitrag auf der EEMEDS 2005 - Energy Efficiency in Motor Driven Systems.

[27]. Finley WR, Mark M, Hodowanec MM, Husssain KS, John L (2004).To Test or Not to Test? Understanding Electrical and Mechanical Tests Performed on Induction Motors, IEEE Ind. Appl. Mag., pp. 22-33.

[28]. Holmquist JR, Rooks JA, Richter ME (2004). Practical Approach for Determining Motor Efficiency in The Field Using Calculated and Measured Values, IEEE Transaction on Industry Applications, 4(1): 242-248.

[29]Zhi G, Habetler TG, Harley RG (2005). A Robust Rotor Temperature Estimator For Induction Machines In The Face Of Changing Cooling Conditions And Unbalanced Supply, IEEE Int. Conf. Electric Machines and Drives, pp. 591-596.

[30]. Khluabwannarat P, Thanmarat C, Tadsuan S, Suechoey B (2007). The Result Analysis Of The Electrical Power And Temperature of 3-Phase Induction Motor Supplied by the PWM Inverter, Int. Conf. Power Eng., pp. 1197-1202.

[31]. Weili H, Weijian H, Lin L (2007). Estimation of Stator Resistance and Temperature Measurement in Induction Motor Using Wavelet Network. Chinese Control Conf., pp. 203-207.

[32] Ganesh RJA, Quaicoe JE, Venkatesan R (2003). A minimum-Loss Robust Scheme for Torque Control of Induction Motors, IEEE Canadian Conf. Elect.Comput. Eng., 1: 275-278.

[33]. Famouri P, Cathey JJ (1991). Loss minimization control of induction motor drive, IEEE Trans. Ind. Appl., 27(1): 32-37.
[34]. Cisz G, Runcos F, Waite S (2009). Comparative Analyses of Standards Temperature Rise Test Methods For Induction Machines, Petroleum Chem. Ind. Conf., pp. 1-6.

[35]. Ohtani T, Takada N, Tanaka K (1992). Vector Control of Induction Motor Without Shaft Encoder, IEEE Trans. Ind. Appl., 28(1): 157-164.

[36]. Williams, R.; McKane, A.; Guijn, Z.; Nadel, S.; Peters, J.; Tutterow, V. (2005): The Chinese Motor System optimisation Experience: Developing a Template for a National Program: Proceedings of EEMEDS 2005 - Energy Efficiency in Motor Driven Systems.

[37]Zhang L, Hasan KM (1999). Neural Network Aided Energy Efficiency Control for a Field-Orientation Induction Machine Drive, IEE Ninth int. Conf. Electrical Machines and Drives, Conf. Pub., 468(0): 356-360.

[38]. A K. Sharma, R. A. Gupta, and Laxmi Srivastava., " A new technique for energy reduction in induction motor drives using artificial neural network" 2005.

[39]. XEnergy (2001): Assessment of the market for compressed air efficiency services, US Department of Energy (ed.). 